\title{
EVALUATION OF GIANT KNOTWEED AND MISCANTHUS AS PERSPECTIVE ENERGY PLANTS AND ASSESSMENT OF PRODUCED BIOFUEL QUALITY INDICATORS
}

Dionizas STREIKUS, Institute of Agricultural Engineering and Safety, Faculty of Agricultural Engineering, Aleksandras Stulginskis University, Studentu str. 15, Akademija, LT-53662 Kaunas reg., Lithuania, dionizasstreikus@ gmail.com (corresponding author) Algirdas JASINSKAS, Institute of Agricultural Engineering and Safety, Faculty of Agricultural Engineering, Aleksandras Stulginskis University, Studentu str. 15, Akademija, LT-53662 Kaunas reg., Lithuania, algirdas.jasinskas@asu.lt

Rolandas DOMEIKA, Institute of Agricultural Engineering and Safety, Faculty of Agricultural Engineering, Aleksandras Stulginskis University, Studentu str. 15, Akademija, LT-53662 Kaunas reg., Lithuania, rolandar.domeika@asu.lt

Sigitas ČEKANAUSKAS, Experimental Station, Aleksandras Stulginskis University, Rapsu str. 7, Noreikiskes, LT-53363 Kaunas reg., Lithuania, sigitas.cekanauskas@asu.lt

Nerijus PEDIŠIUS, Lithuanian Energy Institute, Breslaujos str. 3, LT-44403 Kaunas, Lithuania, nerijus.pedisius@lei.lt Tomas VONŽODAS, Lithuanian Energy Institute, Breslaujos str. 3, LT-44403 Kaunas, Lithuania, tomas.vonzodas@lei.lt Andres ANNUK, Institute of Technology, Estonian University of Life Sciences, Fr. R. Kreutzwaldi str. 56, 51014 Tartu, Estonia, andres.annuk@emu.ee

Giant knotweed (Fallopia sachalinensis) was chosen as a perspective energy plant because it is not a soil demanding plant and belongs to the most efficient herbs in Central Europe as regards high biomass yield. Miscanthus (Miscanthus sinensis) was chosen as a control one. Knotweeds are comparable to wood briquettes and pellets because of their similarparallel mechanical and thermal features. These plants grow in forest environment with an approximate yield productivity of $15 \mathrm{tha}^{-1}$ d.b. (dry basis). Experimental research investigations were performed in the laboratories of Aleksandras Stulginskis University. Giant knotweed and miscanthus biomass was cut, chopped, milled and granulated with a small capacity granulator $\left(250-300 \mathrm{~kg} \mathrm{~h}^{-1}\right)$. Quality parameters of plant preparative and use for energetical objectives were determined. Plant chaff and mill fraction compositions were determined, and quality indicators of the produced pellets were measured - moisture content, density, resistance to compression, elemental composition, ash content and calorific value, also bulk density, fall and natural slope angles. Moisture content reached $7.8 \pm 0.8 \%$; pellet density was $1227.3 \pm 48.6$ $\mathrm{kg} \mathrm{m}^{-3}$. Resistance to compression of giant knotweed pellet was $850 \mathrm{~N}$. Determined ash content was $4.3 \pm 0.01 \%$, and net calorific value of knotweed dry mass was of sufficient height and reached $18.96 \pm 0.28 \mathrm{MJ} \mathrm{kg}^{-1}$. Bulk density reached $509.9 \mathrm{~kg} \mathrm{~m}^{-3}$, natural slope angle was $31.7^{\circ}$ and fall angle was $49.3^{\circ}$.

Keywords: ash content, calorific value, density, elemental composition, knotweed, miscanthus, pellets.

\section{INTRODUCTION}

At present, just about $7 \%$ of energy production in Europe is from renewable energy sources. The European Union imports about $48 \%$ of energy from Russia and Norway. In the year 2006, EU sustainable development strategy forecasted that in 2020 energy production from renewable energy sources would reach $20 \%$. In Lithuania, just $15 \%$ of energy production is produced using renewable energy sources (Janisevičius, 2014). Until the year 2020, heat generation from solid biofuel in Lithuania will reach $67 \%$ (Verbickas et al., 2015).

Wood biofuel is the most widely used sort of fuel in Lithuania. Apart from this sort of solid fuel, other local resources (raw materials) used for energy purposes: straw, waste products of agriculture, peat and energy plants. Energy plants such as willow (Salix viminalis L.), virginia mallow (Sida hermaphrodita L.), fibrous hemp (Cannabis sativa L.), stinging nettle (Urtica dioica L.), cup plant (Silphium perfoliatum L.), miscanthus (Miscanthus sinensis), as well as giant knotweed (Fallopia sachalinensis) can be successfully used in the energy market of Lithuania. These plants are not soil demanding and prefer cool climatic conditions (except miscanthus).

In this paper we would like to introduce the data from the investigations of two energy crops - knotweed and miscanthus (as control one).

Giant knotweed (Fallopia sachalinensis) is native to eastern Asia; it can grow from $1.5 \mathrm{~m}$ to more than $3.5 \mathrm{~m}$ tall. Knotweed is a perennial plant that sprouts from a woody base each year. These plants can reach high productivity of

Copyright (C) 2017 The Authors. Published by Aleksandras Stulginskis University. This is an open-access article distributed under the terms of the Creative Commons Attribution License (CC-BY 4.0), which permits unrestricted use, distribution, and reproduction in any medium, provided the original author and source are credited. 
about $15 \mathrm{t} \mathrm{ha}^{-1}$ d.b. (dry basis). There are several species of knotweed: Japanese knotweed (Fallopia japonica), Giant knotweed (Fallopia sachalinensis), Bohemian knotweed (Fallopia $\times$ bohemica), Himalayan knotweed (Persicaria wallichii), etc. (Prather et al., 2009).

Miscanthus (Miscanthus sinensis) was brought to Europe from the East Asian climatic zone. It is a perennial plant with stems that are of 4 metres height. Miscanthus is sensitive to frost. Under favourable conditions and sufficient moisture in the soil, miscanthus is capable of producing up to $25 \mathrm{t} \mathrm{ha}^{-1} \mathrm{~d}$.b.. The stems of these plants for fuel in the same area can be grown for $20-25$ years (Jakienè et al., 2013).

There are different methods of biomass processing for energy purposes. The most popular technology is to produce pellets from biomass in the late decade of the year.

The aim of this work is to research giant knotweeds and miscanthus pellets quality indicators: ash content, density, humidity, calorific value, and deformation strength.

\section{MATERIALS AND METHODS}

One sort of knotweed and miscanthus was explored. Knotweeds are grown in forest vicinities and miscanthus is cultivated in the test station.

Chopping and milling qualities of the plants that are prepared for solid biofuel production should satisfy the requirements of the combustion chamber of biofuel boiler, chopped mass transportation machinery and storage. Drum chopper of Maral 125 forage harvester used for the first step of stem chopping. Mill Retsch SM 200 used for milling prepared chaff (Streikus et al. 2016).

Fractional composition. Plants flour mass fractional composition determined using sieves with different diameter holes: $0 \mathrm{~mm}, 0.25 \mathrm{~mm}, 0.5 \mathrm{~mm}, 0.63 \mathrm{~mm}, 1 \mathrm{~mm}$ and $2 \mathrm{~mm}$. For this experiment, sieve shaker Retsch AS 200 (Fig 1.) used. The complect of sieves was set on the siewe shaker, and was vibrating 3 minutes with 10 seconds intervals every minute in a horizontal flat. Every fraction part persentage of the remaining mass of sieves is weighed and calculated. In addition, according to research data reliability estimation calculated measurements average with deviation. Each test repeated 3 times.

For pellet production we used granulator with horizontal granulator matrix. Its capacity was $7.5 \mathrm{~kW}$.

Humidity. Pellets packed into cruets and weighed. Afterwards, it was put into a drying chamber (Fig 2.). Samples were dried for 24 hours at $105^{\circ} \mathrm{C}$ temperature. Both the dried samples and empty cruets were weighed . The humidity of all the samples, as well as average humidity with deviation, was calculated.

Pellet density. For the determination of pellet density, various plants pellets weighed and their mass $m$ was determined. Also, were measured by trammel pallets length and diameter measured using trammel pallets and the volume $V$ of the pallets was calculated. According to equation $\rho=m / V$, a single pellet density calculated.

Resistance to compression. The research is done in laboratory using a device INSTRON 5965 (Fig 3.). 5 pellets were selected for each sort of plants. Pellet was pressed until it was damaged. The entireprocess was controlled by a special computer program and data were and fixed in the computer memory disc.

Bulk density determined after filling pellets to a cylindrical plate of the measured volume $(V)$ (which was equal 5 $\left.\mathrm{dm}^{3}\right)$ and not pressing weighed by scale to determine their mass $(m)$, bulk density was calculated by formula: $\rho=m / V$ (Solid biofuels. 2005).

Fly angles. Natural slope angle $\alpha_{\mathrm{n}}$ and fall angle $\alpha_{\mathrm{gr}}$ determined using a special stand which is in Agriculture Engineering and Safety Institute (Siaudinis et al., 2015).

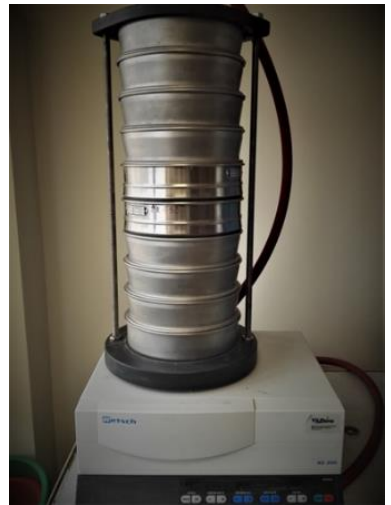

Figure 1. Sieve shaker Retsch AS 200

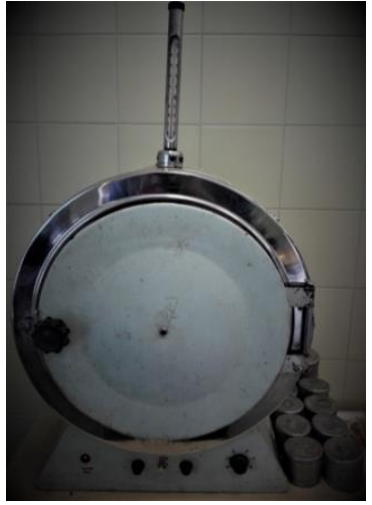

Figure 2. Drying cupboard

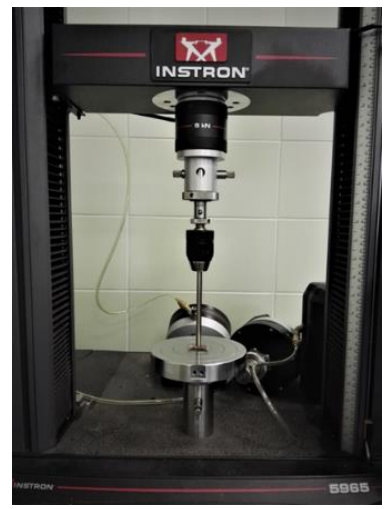

Figure 3. INSTRON 5965

Ash content and calorific value. Tests was done in Lithuanian Energy Institute, Thermal devices test and research laboratory applying standard methodology that is valid in Lithuanian and European countries. Ash content was determined in research device No. 8B/5 according to LST EN 14775:2010 standard requirements. Calorific value determined in research device No. 8B/2 according to LST EN 14918:2010 standard requirements. 


\section{RESULTS AND DISCUSSION}

The particle size distribution of chopped by drum chopper and milled by hammer mill giant knotweed and miscanthus determined.

The particle size distribution or farctional composition of knotweed mill (\%) is given in Fig. 4. Estimated fractional composition of mill, it had been noticed that there was no fraction on a sieve with holes of $2 \mathrm{~mm}$ diameter, and after the milling of giant knotweed chaff very small fraction was produced. A large mill fraction found on $0.25 \mathrm{~mm}$ sieves $(45.4 \pm 3.6 \%)$, and the highest amount of dust found $-46.7 \pm 3.2 \%$.

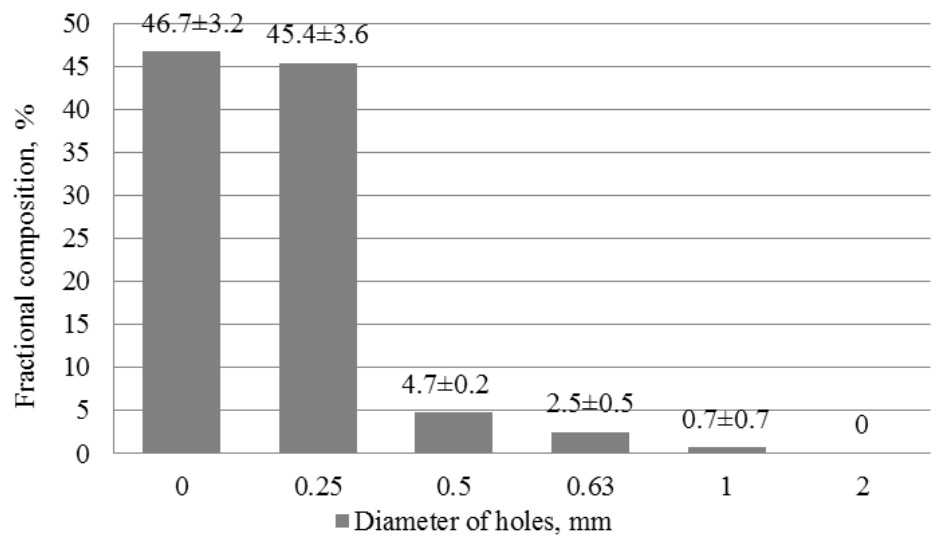

Figure 4. Fractional composition of knotweed mill

The dependance of miscanthus mill fraction (\%) from the holes of sieves is given in Fig. 5. Research results show that if compared to giant knotweed mill, produced miscanthus mill fraction was significantly coarser. The biggest fraction of plant mill accumulated on a sieve with the holes of $0.63 \mathrm{~mm}$ diameter $-46.4 \pm 0.6 \%$, the second biggest on a sieve with the holes of $2 \mathrm{~mm}$ diameter $-31.0 \pm 0.0 \%$, and there was no fraction on a sieve with holes of $0.25 \mathrm{~mm}$ diameter.

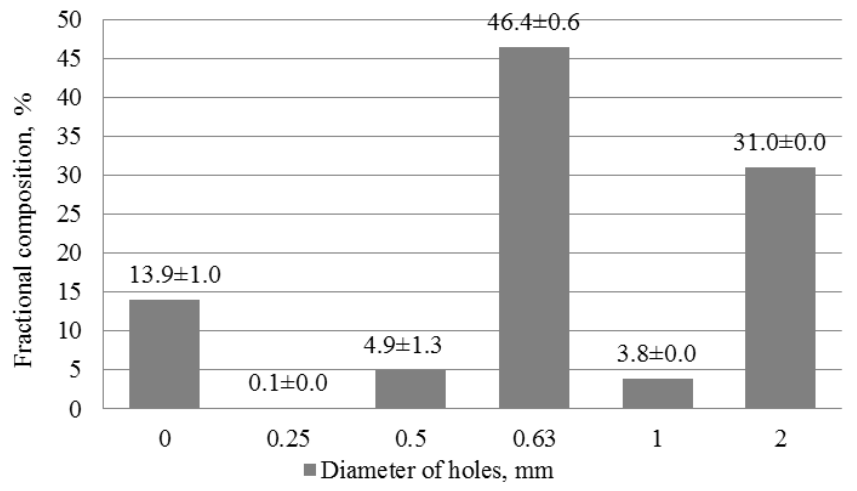

Figure 5. Fractional composition of miscanthus mill

The humidity and density of pellets showed in Table 1 have been determined. Results of investigations show that pellets humidity varies from 7.8 to $8.4 \%$. Density of investigated plants pallets was sufficiently high and reached 1131.6 $-653.6 \mathrm{~kg} \mathrm{~m}^{-3}$ d.b.

Table 1. Main physical-mechanical characteristics of pellets

\begin{tabular}{|l|c|c|}
\hline \multicolumn{1}{|c|}{ Pellets } & Humidity, $\%$ & Pellet density, $\mathrm{kg} \mathrm{m}^{-3}$ \\
\hline Giant knotweed & $7.8 \pm 0.8$ & $\begin{array}{c}1227.3 \pm 48.6 \\
1131.6 \pm 48.6 \mathrm{~d} . \mathrm{b} .\end{array}$ \\
\hline Miscanthus & $8.4 \pm 0.07$ & $\begin{array}{c}713.5 \pm 67.1 \\
653.6 \pm 67.1 \mathrm{~d} . \mathrm{b} .\end{array}$ \\
\hline
\end{tabular}

d.b. - dry basis

The bulk density of giant knotweed pellets reached $509.9 \mathrm{~kg} \mathrm{~m}^{-3}$, natural slope angle $\alpha_{\mathrm{n}}$ was $31.7^{0}$ and fall angle $\alpha_{\mathrm{gr}}$ was $49.3^{\circ}$.

Resistance to compression is an significant parameter for the transportation and storage of pellets. Resistance to the compression of giant knotweed was $850 \mathrm{~N}$, whereas resistance of the compression of miscanthus was only $196 \mathrm{~N}$.

The quality indicators of investigated energy plants pellets in burning facility showed in Table 2 and Fig.6.

Table 2. Pellets ash contents and calorific value (d.b.) 


\begin{tabular}{|l|c|c|}
\hline \multicolumn{1}{|c|}{ Pellets } & Ash content, \% & Calorific value, MJ kg-1 \\
\hline Giant knotweed & $4.28 \pm 0.01$ & $8.84 \pm 0.90$ \\
\hline Miscanthus & $18.96 \pm 0.28$ & $18.95 \pm 0.58$ \\
\hline
\end{tabular}

Ash content of miscanthus was the biggest and reached $8.8 \%$, a lower ash content was of the giant knotweed and reached $4.3 \%$.

The average calorific value of giant knotweed and miscanthus pellets of d.b. was very similar and reached 19.0 $\mathrm{MJ} \mathrm{kg}^{-1}$. Compared to the calorific value of some wood species, the calorific value of these plants pellets is quite great, for example birch has a calorific value of $18.5 \mathrm{MJ} \mathrm{kg}^{-1}$ (Jasinskas and Zvicevičius, 2008).

Other researchers conducted the tests with other species: Japanese knotweed (Fallopia japonica) and Bohemian knotweed $\left(\right.$ Fallopia $\times$ bohemica). The results were as follows: productivity was $13.23-21.41 \mathrm{t}^{-1} \mathrm{~d}$.b. of Japanese knotweed and $6.84-17.74 \mathrm{t} \mathrm{ha}^{-1}$ d.b. of Bohemian knotweed. Moisture content was $16.6-32.3 \%$, ash content - 3.12$4.60 \%$ (Strašil and Kara, 2010).

The pellets of knotweed were investigated by other scientists, and they got the following results: moisture content was $5.93 \%$, ash content - $3.99 \%$, calorific value - $17.62 \mathrm{MJ} \mathrm{kg}^{-1}$ (Malatak and Passian, 2011).

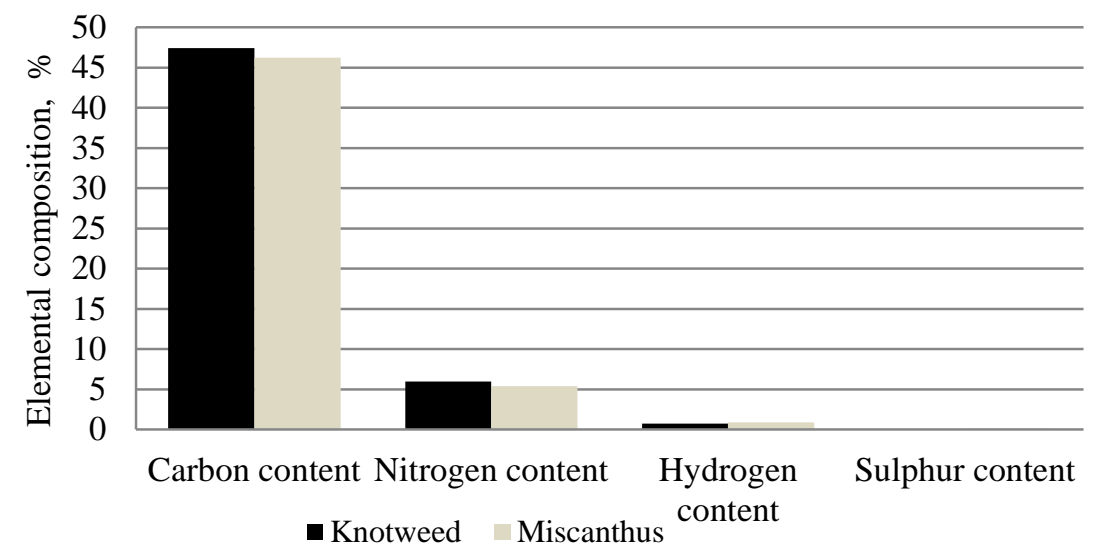

Figure 6. Pellets elemental composition

Having performed the research of knotweed pellets properties, it can be stated that it is proper to use as biofuel due to the fact that its characteristics are close to the properties of wood-based biofuels. Knotweeds yield can be produced in one year, but the price of this plant pellets can be higher than the price of wood pellets.

\section{CONCLUSIONS}

1. The technical means of giant knotweed, and the preparation and usage for energy purposes of miscanthus explored. Technique for plant chopping, milling and pelleting investigated.

2. By establishing the fineness of plant mill fraction it can be said that knotweed was milled into too small fraction, because too high amount of knotweed dust (less than $0.25 \mathrm{~mm}$ ) was found $-46.7 \pm 3.2 \%$, and there was no fraction on a sieve with $2 \mathrm{~mm}$ diameter holes.

3. Determined miscanthus mill fraction was coarse, because the biggest mill fraction was on 0.63 mm diameter sieve $46.4 \pm 0.6 \%$.

4. Set pellets humidity varies from 7.8 to $8.4 \%$. Density in dry basis (d.b.) of investigated plants was sufficiently high; it reached $1131.6-653.6 \mathrm{~kg} \mathrm{~m}-3$ d.b.

5. 5. The ash content of miscanthus was the highest and obtained $8.8 \%$, ash content of giant knotweed was about twice as low and reached $4.3 \%$. Determined calorific value of giant knotweed and miscanthus pellets was high enough, it was even $19.0 \mathrm{MJ} \mathrm{kg}-1 \mathrm{~d} . \mathrm{b}$.

6. After evaluation of knotweed pellets properties, it can be stated that it is proper to use as solid biofuel, because its characteristics are very similar to the properties of wood biofuels.

\section{REFERENCES}

1. CEN/TC 14774-1. 2005. Solid biofuels - Methods for the determination of moisture content Oven dry method - Part 1: Total moisture - Reference method.

2. Instruction manual of pellet mill. 2011. Granulator Peleciarka 7.5. Company POLEXIM, Poland, pp. 7.

3. Jakiene, E., Liakas V., Klimas, E., Bačkaitis, J. 2013. Technologies for growing energy crops and woody plants. Akademija, 199 p. [In Lithuanian].

4. Janisevičius, G. 2014. Wood and agro-biofuel. Sustainable development strategy and practice Research work. pp. 143. 
5. Jasinskas, A., Simonavičiūtè, R., Šiaudinis, G., Liaudanskienè, I., Antanaitis, Š., Arak, M., Olt, J. 2014. The assessment of common mugwort (Artemisia vulgaris L.) and cup plant (Silphium perfoliatum L.) productivity and technological preparation for solid biofuel. Zemdirbyste-Agriculture, Vol. 101, No. 1, pp. 19-26 https://doi.org/10.13080/z-a.2014.101.003

6. Jasinskas, A., Zvicevičius, E. 2008. Biomass production engineering: Educational book. Akademija, 99 p. [In Lithuanian].

7. LST EN 14775:2010 standard. Ash content test.

8. Macak, M., Nozdrovicky L., Hussein, A.O. 2015. Effect of preheating and different moisture content of input materials on durability of pellets made from different phytomass content. Acta Technologica Agriculturae, Vol. 1, pp. 22-27. https://doi.org/10.1515/ata-2015-0006

9. Malatak, J., Passian, L., 2011. Heat-emission analysis of small combustion equipments for biomass. Research in Agricultural Engineering. Vol. 57, pp. 37-50.

10. Niedziołka, I., Szpryngiel, M., Kachel-Jakubowska M., Kraszkiewicz, A., Zawislak, K., Sobczak, P. \& Nadulski, R. 2015. Assessment of the energetic and mechanical properties of pellets produced from agricultural biomass. Renewable Energy, Vol. 76, pp. 312-317.https://doi.org/10.1016/j.renene.2014.11.040

11. Prather T.S., Miller T.W. \& Robins S.S. 2009. Knotweed shrubs: identification, biology and management. Available at: https://catalog.extension.oregonstate.edu/pnw 610.

12. Solid biofuels. Determination of bulk density. 2005. LST CEN/TS 15103.2005 [In Lithuanian].

13. Strašil, Z., Kára, J. 2010. Study of knotweed (Reynoutria) as possible phytomass resource for energy and industrial utilization. Research of Agricultural Engineering, Vol. 56, pp. 85-91.

14. Streikus, D., Jasinskas, A., Arak, M., Jotautienė E., Mieldažys, R., Čekanauskas, S., Jankauskienė, Z. 2016. Investigations of fibre plants preparation and utilization of solid biofuels. Agronomy research, Vol. 14, No. 1, pp. 259-268

15. Šiaudinis, G., Jasinskas, A., Šarauskis, E., Steponavičius, D., Karčiauskienė, D., Liaudanskienė, I. 2015. The assessment of Virginia mallow (Sida hermaphrodita Rusby) and cup plant (Silphium perfoliatum L.) productivity, physicoemechanical properties and energy expenses. Energy, Vol. 93, Iss. 1, pp. 606-612. https://doi.org/10.1016/j.energy.2015.09.065

16. Verbickas, D., Juknys, R. \& Kleišmantas, A. 2013. The use of solid biofuels in Lithuania for heat production, future prospects and the impact on the environment. Energetika, Vol. 59, No. 3, pp. 144 [In Lithuanian]. 